\title{
Sulphur Metabolism of Puccinia graminis f.sp. tritici in Axenic Culture
}

\author{
By N. K. HOWES* AND K. J. SCOTT \\ Department of Biochemistry, University of Queensland, \\ St Lucia, Queensland, Australia, 4067
}

(Received I December 1972)

\begin{abstract}
SUMMARY
Axenic cultures of Puccinia graminis f. sp. tritici cannot reduce sulphate for sulphur-amino-acid synthesis. Although $\left[{ }^{35} \mathrm{~S}\right]$ sulphide is incorporated into these amino acids, the fungus still has a nutritional requirement for a sulphur amino acid. Most of the incorporated sulphide was found in the culture filtrate in the form of cysteine, S-methylcysteine, glutathione and cysteinylglycine. There were appreciable amounts of labelled methionine in mycelial protein but very little of this amino acid appeared in the culture filtrate. The results indicate that the nutritional requirements for sulphur amino acids by the rust fungus is caused by loss of cysteine and some of its derivatives into the medium.
\end{abstract}

\section{INTRODUCTION}

It was shown previously (Howes \& Scott, 1972) that saprophytic mycelium of the wheat stem rust fungus has a nutritional requirement for cysteine, homocysteine or methionine which could not be replaced by sulphide or thiosulphate, the sulphur precursors of cysteine (Thompson, 1967). Of other fungi tested, most utilize sulphate as a source of sulphur, the major exceptions are aquatic Phycomycetes: most Saprolegniales and all Blastocladiales (Cantino, I950, 1955). However, fungi unable to utilize sulphate can usually grow in the presence of reduced inorganic sulphur, and only a few organisms require the organic forms of sulphur, cysteine and methionine (Barner \& Cantino, 1952; Ingraham \& Emerson, 1954).

Thus the nutritional requirement of the wheat stem rust fungus for sulphur amino acids was of considerable interest, particularly in view of the relatively non-specific nutritional requirements of this fungus for carbohydrate (Maclean \& Scott, 1970) and nitrogen (Howes \& Scott, 1972) sources. The biochemical basis for this sulphur requirement was investigated by studying the synthesis of cysteine from inorganic sulphur; its metabolic interconversion into other sulphur amino acids; and the fate of these compounds in the mycelium.

\section{METHODS}

Organism. Subcultures of a persistently vegetative isolate (strain VI) of the wheat stem rust fungus (Puccinia graminis [Pers.] f.sp. tritici [Eriks. and E. Henn.] race I26-Anz-6, 7) were used in these studies. The isolation and some characteristics of this strain have been reported elsewhere (Maclean \& Scott, 1970; Maclean, Scott \& Tommerup, 1971). Subcultures were checked for pathogenicity at the conclusion of this investigation by the epidermis-removal method of infection (Maclean et al. 1971) and were found readily to infect wheat leaves.

* Present address: Research Station, Department of Agriculture, Winnipeg, Manitoba, Canada. 
Preparation of mycelium. Mycelium was subcultured at monthly intervals by transferring cultures to a sterile blender, fragmenting for 3 to $4 \mathrm{~s}$ and dispensing samples (I to $5 \mathrm{ml}$ ) into $250 \mathrm{ml}$ conical flasks with $50 \mathrm{ml}$ fresh medium containing: Czapek's minerals, $0.3 \%$ (w/v) tri-sodium citrate, $4 \%(\mathrm{w} / \mathrm{v})$ glucose, I \% (w/v) Evans's peptone and $0.04 \%(\mathrm{w} / \mathrm{v})$ histidine- $\mathrm{HCl}$ at $\mathrm{pH} 6 \cdot 0$. All media were sterilized by autoclaving at $\mathrm{I} 5 \mathrm{lb} / \mathrm{in}^{2}\left(\mathrm{I} 2 \mathrm{I}{ }^{\circ} \mathrm{C}\right.$ ) for a maximum of $10 \mathrm{~min}$.

Mycelium to be used for experiments was harvested 3 weeks after subculturing. Mycelium was collected by centrifugation and washed twice in the basal medium: Czapek's minerals, $0.3 \%$ tri-sodium citrate, $4 \%$ glucose and 6 mM-glutamine at $\mathrm{pH} 6.0$. After pre-incubation in basal medium for 3 days the mycelium was resuspended in various test media and maintained at $23{ }^{\circ} \mathrm{C}$ in the dark. At the conclusion of the experiment (usually 5 days) the mycelium was harvested by centrifugation and washed with a small volume of distilled water ( 2 to $3 \mathrm{ml}$ ). The supernatants were pooled, filtered and evaporated to dryness. After oxidation with performic acid for $15 \mathrm{~min}$ at $25^{\circ} \mathrm{C}$, excess performic acid was removed by evaporation and the residue dissolved in $50 \%$ ethanol $(4 \mathrm{ml})$. This was referred to as the culture filtrate.

Preparation of the protein hydrolysate. The mycelium was washed with ethanol containing $0 . \mathrm{I} \%(\mathrm{w} / \mathrm{v}) \beta$-mercaptoethanol, and homogenized in glass Ten Broeck hand homogenizers containing $\mathrm{O} \cdot \mathrm{I} \mathrm{M}-\mathrm{NaOH}$. The homogenate was incubated at $60^{\circ} \mathrm{C}$ for $30 \mathrm{~min}$ then centrifuged. The pellet was re-incubated in $\mathrm{O} . \mathrm{I} \mathrm{M}-\mathrm{NaOH}$, centrifuged and the trichloroacetic acid precipitated protein was collected by centrifugation and washed with ethanol and ether to remove lipids (Schmidt \& Thannhauser, 1945). The dried pellet was dissolved in $5 \mathrm{ml}$ performic acid and after standing for $\mathrm{I} \mathrm{h}$ at $25^{\circ} \mathrm{C}, 5 \mathrm{ml}$ ethanol added and the protein dried under vacuum. The oxidized protein was dissolved in $2.0 \mathrm{ml} \mathrm{O} . \mathrm{I} \mathrm{M}-\mathrm{NaOH}$ by incubating at $60^{\circ} \mathrm{C}$ for $15 \mathrm{~min}$ and samples (O. I ml) removed for protein estimation by the method of Lowry, Rosebrough, Farr \& Randall (I95I). Protein was hydrolysed with $6 \mathrm{~N}-\mathrm{HCl}$ at $110^{\circ} \mathrm{C}$ for $20 \mathrm{~h}$, the hydrolysate cooled, filtered and evaporated to dryness. The residue was dissolved in $50 \%$ ethanol ( $\mathrm{I} \mathrm{ml).}$

Electrophoresis. Samples of the culture filtrates and protein hydrolysates (5 to $20 \mu \mathrm{l}$ ) were spotted, together with standards, onto thin-layer plates coated with cellulose/silica gel $3: I(w / w)$. The plates were sprayed with buffer and electrophoresis carried out in an apparatus similar to that described by Katz \& Lewis (I966) at 2000 volts and 20 to $45 \mathrm{~mA}$ usually for $15 \mathrm{~min}$. The buffers used for particular $\mathrm{pH}$ values were: $\mathrm{pH}$ I $\circ(60 \mathrm{ml}$ acetic acid, $15 \mathrm{ml}$ formic acid/l); $\mathrm{pH} 2.5\left(5 \mathrm{ml}\right.$ formic acid/l); $\mathrm{pH}_{3.2}(30 \mathrm{ml}$ acetic acid, $\mathrm{r} \cdot 2 \mathrm{ml}$ pyridine/l); $\mathrm{pH} 5.3(3 \mathrm{ml}$ acetic acid, $7.5 \mathrm{ml}$ pyridine/ $) ; \mathrm{pH} 6.3(3 \mathrm{ml}$ acetic acid, $50 \mathrm{ml}$ pyridine/l).

Chromatography. All chromatography was carried out on thin-layer plates coated with $250 \mu \mathrm{m}$ thickness of cellulose/silica gel $3: \mathrm{I}(\mathrm{w} / \mathrm{w})$ and using ascending solvent systems.

Measurement of radioactivity. After electrophoresis or chromatography the thin-layer plates were dried with warm air, and radioactive compounds located by autoradiography and by spraying duplicate samples with a cadmium ninhydrin solution (Heilman, Barrollier \& Watzke, 1957). The regions of interest were scraped into $20 \mathrm{ml}$ vials containing $5 \mathrm{ml}$ scintillant (4 g 2,5-Diphenyloxazole, $50 \mathrm{mg}$ I,4-bis-2-(4-methyl-5-phenyloxazolyl)-benzene/1 toluene). After standing overnight radioactivity was measured and c.p.m. corrected for quench by using an external standard. Samples of radioactive solutions were counted by absorption into glass fibre discs, drying the discs under an infrared lamp and counting in $5 \mathrm{ml}$ scintillant.

Co-crystallization. A sample of the culture filtrate was mixed with a solution of the 
authentic compound. This was acidified with $\mathrm{HCl}$ and crystallized from $80 \%$ ethanol at $-20{ }^{\circ} \mathrm{C}$, the crystals collected by filtration, washed with $80 \%$ ethanol and dried under vacuum over $\mathrm{NaOH}$ flakes. Recrystallization was repeated until three consecutive crystallizations had the same specific activity or the specific activity approached zero. For homocysteic acid the culture filtrate was passed through a $5 \times 0.4 \mathrm{~cm}$ column of Dowex $50\left(\mathrm{H}^{+}\right)$ resin and the $4 \mathrm{M}$-ammonium eluate used for co-crystallization.

Labelling with $\left[{ }^{35}\right.$ S] sulphate. Carrier-free sulphate $(3 \mathrm{mCi})$ was added to $20 \mathrm{ml}$ of the basal medium in which $\mathrm{MgSO}_{4}$ was replaced by $\mathrm{MgCl}_{2}$. The final sulphate concentration was $0.07 \mathrm{~mm}$ with a specific activity of $2000 \mathrm{mCi} / \mathrm{mmole}$. The mycelium was incubated for 5 days in a $100 \mathrm{ml}$ conical flask.

Labelling with hydrogen $\left[{ }^{35} \mathrm{~S}\right]$ sulphide. Hydrogen sulphide gas (I $\mathrm{mCi}$ ) having a specific activity of I I $5 \mathrm{mCi} / \mathrm{mmole}$ was diluted with dry nitrogen and samples (I to $2 \mathrm{ml}$ ) injected through silicone stoppers into $20 \mathrm{ml}$ vials. Each vial contained $2.0 \mathrm{ml}$ medium plus mycelium and Io vials were used for each treatment. The calculated sulphide concentration was $0.5 \mathrm{~mm}$ if all sulphide was in solution. Two treatments were used: one group of vials contained basal medium and the other contained basal medium supplemented with $3 \mathrm{~mm}$ cysteine. Both treatments were harvested after 5 days.

Labelling with $\left[\mathrm{I}^{-14} \mathrm{C}\right]$ methionine. $\left[\mathrm{I}^{-14} \mathrm{C}\right]$ Methionine $(5 \mu \mathrm{Ci})$ having a specific activity of Io $\mathrm{mCi} / \mathrm{mmole}$ was added to $5 \mathrm{ml}$ basal medium. Mycelium was added and the medium dispensed into two $20 \mathrm{ml}$ vials closed with loose-fitting screw caps. The mycelium and culture filtrate were harvested after 5 days and distribution of radioactivity determined.

Labelling with $\left[2-{ }^{14} \mathrm{C}\right]$ glycine. $\left[2{ }^{14} \mathrm{C}\right]$ Glycine $(7 \cdot 5 \mu \mathrm{Ci})$ having a specific activity of Io $\mathrm{mCi} / \mathrm{mmole}$ was added to $5 \mathrm{ml}$ basal medium supplemented with O.I mM-methionine. Mycelium was added and the medium dispensed into $20 \mathrm{ml}$ vials and harvested after 5 days. A second treatment contained basal medium supplemented with $3 \mathrm{~mm}$-cysteine and was harvested after 5 days of incubation. The mycelium was grown under the same conditions as the $\left[\mathrm{I}-{ }^{14} \mathrm{C}\right]$ methionine-fed mycelium and was subsequently treated in the same way.

Sulphate uptake. The incorporation of sulphate into rust mycelium was tested by means of the method of Benko, Wood \& Segel (1967). For comparison, wild-type mycelium of Neurospora crassa (strain 80702) was tested for its ability to incorporate sulphate.

Fragmented rust mycelium was incubated in induction medium, containing Czapek's minerals $\left(\mathrm{MgSO}_{4}\right.$ replaced by $\mathrm{MgCl}_{2}$ giving a final sulphate concentration of $\left.0.07 \mathrm{mM}\right)$, $6 \mathrm{~mm}$ glutamine and $4 \%$ glucose at $\mathrm{pH} 6 \cdot 0$, for $\mathrm{I} 4 \mathrm{~h}$ at $23{ }^{\circ} \mathrm{C}$. The mycelium was harvested, washed and resuspended in $50 \mathrm{ml}$ uptake medium containing $0 . \mathrm{I} \% \mathrm{NaNO}_{3}, 0.50 \% \mathrm{NaH}_{2} \mathrm{PO}_{4}$, $0.05 \% \mathrm{MgCl}_{2}$ and $4 \%$ glucose at $\mathrm{pH} 6 \cdot 0$. After shaking for $10 \mathrm{~min},{ }^{35} \mathrm{SO}_{4}$ was added to give a final sulphate concentration of $0.4 \mathrm{~mm}$ and $\mathrm{I} \cdot 36 \times 10^{6}$ d.p.m. $/ \mathrm{ml}(\mathrm{I} \cdot 6 \mathrm{mCi} / \mathrm{mM})$. Samples (IO ml) were removed at short intervals, diluted with I $\mathrm{ml} \mathrm{I} \mathrm{M-Na} \mathrm{SO}_{4}$, immediately filtered, washed with O.I M- $\mathrm{Na}_{2} \mathrm{SO}_{4}$ then distilled water. The mycelial mat was placed in a $20 \mathrm{ml}$ vial with I $\mathrm{ml}$ water and Io $\mathrm{ml}$ Bray's solution (Bray, 1960) and radioactivity measured after standing overnight. The contents of each scintillation vial were filtered; the mycelium was washed with acetone, then water, and dried overnight at $100{ }^{\circ} \mathrm{C}$. Each $10 \mathrm{ml}$ sample contained approximately $15 \mathrm{mg}$ dry wt mycelium. Sulphate uptake in each sample was corrected for variations in dry wt.

Neurospora crassa mycelium was grown in a liquid medium (Ryan, Beadle \& Tatum, I943) for 3 days, fragmented and suspended in induction medium with agitation for $14 \mathrm{~h}$. Sulphate uptake was measured as described for rust mycelium.

Chemicals. All chemicals were of analytical grade purity. Unless otherwise stated amino acids were of the L-isomer. Hydrogen $\left[{ }^{35}\right.$ S $]$ sulphide, $\left[{ }^{35} \mathrm{~S}\right]$ sulphate, $\left[\mathrm{I}^{14} \mathrm{C}\right]$ methionine and 
Table I. Conversion of $\left[{ }^{35}\right.$ S] sulphate and $\left[{ }^{35}\right.$ S] sulphide into cysteine by Puccinia graminis tritici in axenic culture*

\begin{tabular}{|c|c|c|}
\hline \multirow[b]{2}{*}{ Location } & \multicolumn{2}{|c|}{$\begin{array}{l}\text { Incorporation into cysteine (isolated as } \\
\text { cysteic acid } \dagger \text { ) }\end{array}$} \\
\hline & $\begin{array}{c}{\left[{ }^{35} \text { S]Sulphate }\right.} \\
\text { (d.p.m./mg protein } \ddagger \text { ) }\end{array}$ & $\begin{array}{c}{\left[{ }^{35} \text { S]Sulphide }\right.} \\
\text { (d.p.m./mg protein } \S)\end{array}$ \\
\hline Protein & $<200$ & 85500 \\
\hline Culture filtrate & $<1600$ & 48500 \\
\hline
\end{tabular}

* Medium contained: $4 \%$ glucose, $0.3 \%$ citrate, Czapek's minerals and 6 mm-glutamine at pH 6.0 .

$\uparrow$ Identified by electrophoresis and co-crystallization.

$\ddagger$ Mycelium contained $12.35 \mathrm{mg}$ protein $\left(250 \mu \mathrm{Ci}{ }^{35} \mathrm{SO}_{\mathrm{d}} / \mathrm{mg}\right.$ protein).

$\S$ Mycelium contained $4.94 \mathrm{mg}$ protein $\left(200 \mu \mathrm{Ci} \mathrm{H}_{2}{ }^{35} \mathrm{~S} / \mathrm{mg}\right.$ protein).

[2-14C]glycine were purchased from the Radiochemical Centre, Amersham, Buckinghamshire. Cysteinylglycine was prepared from glutathione by mild acid hydrolysis with 0.6 $\mathrm{M}-\mathrm{HCl}$ at $100{ }^{\circ} \mathrm{C}$ for $45 \mathrm{~min}$ (Tkachuk, 1970). This was contaminated with glutamic acid and glutathione. DL-Homocysteic acid was prepared from DL-homocysteine thiolactone $\mathrm{HCl}$ by oxidation with performic acid and homocysteic acid recrystallized from $80 \%$ ethanol. Methionine sulphone and S-methylcysteine sulphone were prepared from methionine and S-methylcysteine respectively by quantitative oxidation with performic acid. DL-Homocysteic acid, methionine sulphone and S-methylcysteine sulphone were shown to be homogeneous by electrophoresis at $\mathrm{pH} \mathrm{I} \cdot 9$ and chromatography with phenol-water (4:I) as the developing solvent.

\section{RESULTS}

\section{Conversion of $\left[{ }^{35}\right.$ S]sulphate and $\left[{ }^{35}\right.$ S $]$ sulphide into cysteine}

Mycelium was exposed to $\left[{ }^{35} \mathrm{~S}\right]$ sulphate and $\left[{ }^{35} \mathrm{~S}\right]$ sulphide for 5 days. Both mycelial protein and the culture filtrates were examined for the presence of cysteine (as cysteic acid). Cysteic acid was separated from the protein hydrolysate by electrophoresis at $\mathrm{pH} \mathrm{I} \cdot 9$ and radioactivity determined. Radioactive cysteic acid was recovered from mycelium and culture filtrate after feeding with $\left[{ }^{35} \mathrm{~S}\right]$ sulphide but not $\left.{ }^{35} \mathrm{~S}\right]$ sulphate (Table I).

Sulphate uptake was tested by measuring the rate of $\left.{ }^{35} \mathrm{~S}\right]$ sulphate incorporation into mycelium. Rust mycelium showed a linear uptake of sulphate at a rate of $0.03 \mu$ mole $\mathrm{SO}_{4} / \mathrm{g}$ dry wt/min (Fig. I). This rate compared favourably with that of Neurospora crassa under similar conditions, considering that Neurospora crassa is a faster growing fungus.

\section{Utilization of $\left[{ }^{35}\right.$ S]sulphide}

Table 2 shows the distribution of radioactivity in compounds isolated from the protein hydrolysate and the culture filtrate of mycelium exposed to $\left[{ }^{35} \mathrm{~S}\right]$ sulphide in the presence and absence of cysteine. The identification of these compounds was based on their electrophoretic behaviour at $\mathrm{pH} \mathrm{I} \cdot 9$ and $\mathrm{pH} 3 \cdot 2$. In both cases radioactive cysteic acid and methionine sulphone were present in the protein hydrolysates. The culture filtrates contained radioactive cysteic acid, S-methylcysteine sulphone and the oxidized forms of glutathione and cysteinylglycine.

In the absence of cysteine almost as much $\left[{ }^{35} \mathrm{~S}\right]$ cysteic acid was present in the culture filtrate as was in mycelial protein. In contrast, very little $\left.{ }^{35} \mathrm{~S}\right]$ methionine sulphone was present in the culture filtrate compared with that present in the protein hydrolysate. Thus methionine sulphur accounted for $25 \%$ of the radioactivity in the protein, but accounted 


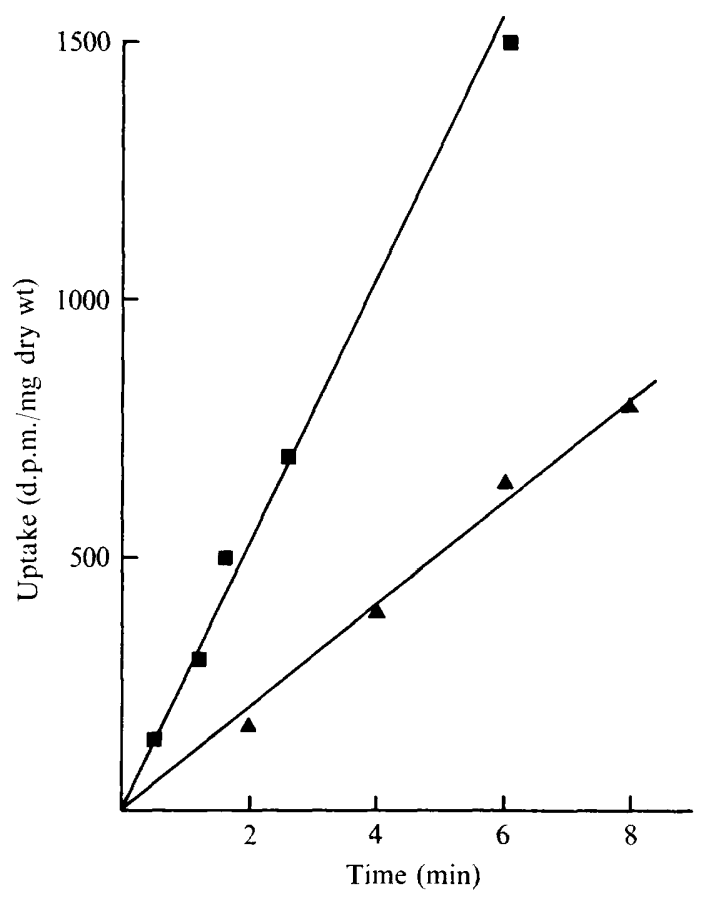

Fig. I. ${ }^{35}$ S]Sulphate uptake by Puccinia graminis tritici mycelium (A) and by Neurospora crassa mycelium (匚). Sulphate concentration was $0.4 \mathrm{mM}(\mathrm{I} \cdot 6 \mathrm{mCi} / \mathrm{mmole})$.

for less than I $\%$ of the radioactivity in the culture filtrate. Furthermore, most of the other radioactivity in the culture filtrate was in the form of cysteine containing peptides (Table 2).

In the presence of cysteine similar compounds were radioactive, although there was a reduction in the total amount of sulphur-35 present in sulphur amino acids and peptides, particularly those incorporated into protein (Table 2).

\section{Utilization of $\left[{\left.\mathrm{I}-{ }^{14} \mathrm{C}\right] \text { methionine }}^{2}\right.$}

To determine if homocysteic acid was also present in the culture filtrate, $\left[\mathrm{I}^{14} \mathrm{C}\right]$ methionine was offered to mycelium with the aim of labelling homocysteine without labelling cysteine, S-methylcysteine, cysteinylglycine or glutathione. This would enable the identification of homocysteic acid which was difficult to separate from cysteic acid and oxidized glutathione. Following electrophoresis of sample of the culture filtrate at $\mathrm{pH}_{\mathrm{I}} \cdot 9$, no radioactivity was detected in the homocysteic acid region, although methionine sulphone, cystathionine and a region at the origin were radioactive (Table 3 ). The absence of $\left[{ }^{14} \mathrm{C}\right]$ homocysteic acid was confirmed by co-crystallization of the culture filtrate with authentic homocysteic acid. $\left[{ }^{14} \mathrm{C}\right]$ Cystathionine was identified by co-electrophoresis at $\mathrm{pH} \mathbf{1} \cdot 9$ with authentic oxidized cystathionine, co-chromatography in butanol acetic acid-water ( $4: \mathrm{I}: \mathrm{I}$ ) and phenolwater (4: I) and its stability to mild acid hydrolysis ( $2 \mathrm{~N}-\mathrm{HCl}$ at $100{ }^{\circ} \mathrm{C}$ for $2 \mathrm{~h}$ ). This shows that negligible amounts of homocysteine were released into the culture filtrate although $\left[\mathrm{I}^{-14} \mathrm{C}\right] \mathrm{methionine}$ was converted to cystathionine via homocysteine.

The radioactive compound remaining at the origin after electrophoresis at $\mathrm{pH} \mathrm{I} \cdot 9$ behaved as an organic acid; it was negatively charged at $\mathrm{pH}_{3} \cdot 2$, not retained by a cation exchange resin and had a high $R_{\mathrm{F}}(0 \cdot 75)$ when separated by chromatography in phenol-water 
Table 2. Utilization of $\left[{ }^{35}\right.$ S $]$ sulphide by Puccinia graminis tritici in the absence and presence of cysteine in the culture medium

\begin{tabular}{|c|c|c|c|}
\hline Location & Compound & $\begin{array}{c}\text { Basal medium* } \\
\text { (d.p.m./mg protein } \dagger \text { ) }\end{array}$ & $\begin{array}{c}\text { Basal medium }+ \\
3 \text { mM-cysteine } \\
\text { (d.p.m./mg protein } \ddagger \text { ) }\end{array}$ \\
\hline Protein & $\begin{array}{l}\text { Cysteine } \\
\text { Methionine }\end{array}$ & $\begin{array}{l}85000 \\
30000\end{array}$ & $\begin{array}{r}15300 \\
3300\end{array}$ \\
\hline Culture filtrate & $\begin{array}{l}\text { Cysteine } \\
\text { Methionine } \\
\text { Glutathione } \\
\text { Cysteinylglycine } \\
\text { S-Methylcysteine } \$ ?\end{array}$ & $\begin{array}{r}66500 \\
2400 \\
57000 \\
202000 \\
20000\end{array}$ & $\begin{array}{r}73000 \\
2300 \\
26000 \\
76400 \\
4450\end{array}$ \\
\hline
\end{tabular}

* Basal medium contained: $4 \%$ glucose, $0.3 \%$ citrate, Czapek's minerals and 6 mm-glutamine at pH 6.0 .

$\dagger$ Mycelium contained $4.94 \mathrm{mg}$ protein.

$¥$ Mycelium contained $4.83 \mathrm{mg}$ protein.

$\S$ Isolated as cysteic acid, methionine sulphone, S-methylcysteine sulphone.

Table 3. Utilization of $\left[\mathrm{I}^{-14} \mathrm{C}\right]$ methionine by Puccinia graminis tritici in axenic culture*

\begin{tabular}{|c|c|c|}
\hline \multirow[b]{2}{*}{ Compound } & \multicolumn{2}{|c|}{ Location } \\
\hline & $\begin{array}{c}\text { Protein } \\
\text { (d.p.m./mg protein } \dagger \text { ) }\end{array}$ & $\begin{array}{l}\text { Culture filtrate } \\
\text { (d.p.m./mg protein } \dagger \text { ) }\end{array}$ \\
\hline Methionine & 58000 & 845000 \\
\hline Homocysteine $\ddagger$ & - & $<3500$ \\
\hline Cystathionine & - & 39500 \\
\hline$\alpha$-Ketobutyrate? & - & I I 90000 \\
\hline
\end{tabular}

* Medium contained: $4 \%$ glucose, $0.3 \%$ citrate, Czapek's minerals, 6 mm glutamine and 0.1 mm-methionine at $\mathrm{pH} 6 \cdot 0$.

$\dagger$ Mycelium contained $\mathrm{I} \cdot 22 \mathrm{mg}$ protein.

$\ddagger$ Determined by co-crystallization.

(4:I). This compound may be $\alpha$-ketobutyrate, derived from the $\gamma$ elimination of cystathionine (Delavier-Klutchko \& Flavin, I965).

In the ${ }^{35}$ S]sulphide-labelling experiments the vials were sealed to contain the hydrogen sulphide gas, and the mycelium could have been under anaerobic conditions. Such conditions may promote the release of sulphur compounds. This was further investigated by labelling rust mycelium with $\left[{ }^{14} \mathrm{C}\right]$ glycine under aerobic conditions.

The protein isolated from mycelium labelled with $\left[2-{ }^{14} \mathrm{C}\right]$ glycine contained radioactive glycine, serine and cysteic acid, suggesting that glycine was converted to serine and then to cysteine (Table 4 ). The culture filtrate contained in addition to $\left[{ }^{14} \mathrm{C}\right]$ glycine, labelled compounds corresponding to serine, cysteic acid, glutathione (oxidized), cysteinylglycine (oxidized) and S-methylcysteine sulphone. These were identified by electrophoresis at $\mathrm{pH} \mathrm{r} \cdot 9$ and $\mathrm{pH} 3 \cdot 2$. Two unidentified compounds were also present in the culture filtrate, one of these having the same electrophoretic mobility at $\mathrm{pH} \mathrm{I} \cdot 9$ as methionine sulphone. However, co-crystallization of the culture filtrate with authentic methionine sulphone showed that only $15 \%$ of this activity ( 2700 d.p.m./mg protein) could be accounted for as methionine sulphone.

Radioactive compounds isolated from the culture filtrate of mycelium labelled with $\left[2-{ }^{14} \mathrm{C}\right]$ glycine were subjected to mild acid hydrolysis $\left(2 \mathrm{M}-\mathrm{HCl}\right.$ at I IO ${ }^{\circ} \mathrm{C}$ for I $\left.\mathrm{h}\right)$. Radioactivity in cysteinylglycine, glutathionine and the two unidentified compounds was released 
Table 4. Utilization of $\left[2-{ }^{14} \mathrm{C}\right]$ glycine by Puccinia graminis tritici in axenic culture

\begin{tabular}{|c|c|c|c|}
\hline Location & Compound & $\begin{array}{c}\text { Basal medium*t } \\
\text { o.I mM-methionine } \\
\text { (d.p.m./mg protein } \dagger \text { ) }\end{array}$ & $\begin{array}{c}\text { Basal medium }+ \\
3 \text { mM-cysteine } \\
\text { (d.p.m./mg protein } \ddagger \text { ) }\end{array}$ \\
\hline Protein & $\begin{array}{l}\text { Cysteine } \\
\text { Serine } \\
\text { Glycine }\end{array}$ & $\begin{array}{r}600 \\
3000 \\
12100\end{array}$ & $\begin{array}{r}885 \\
4900 \\
9300\end{array}$ \\
\hline Culture filtrate & $\begin{array}{l}\text { Cysteine } \\
\text { Serine } \\
\text { Glycine } \\
\text { Glutathione } \\
\text { Cysteinylglycine } \\
\text { S-methylcysteine } \\
\text { Unidentified Peptides }\end{array}$ & $\begin{array}{r}17100 \\
91000 \\
4050000 \\
19000 \\
56400 \\
57000 \\
66000\end{array}$ & $\begin{array}{r}4600 \\
10200 \\
2420000 \\
6500 \\
29600 \\
32100 \\
44000\end{array}$ \\
\hline
\end{tabular}

* Basal medium contained: $4 \%$ glucose, $0.3 \%$ citrate, Czapek's minerals and 6 mM-glutamine at pH 6.0 .

$\dagger$ Mycelium contained $\mathrm{I} \cdot 5 \mathrm{I} \mathrm{mg}$ protein.

$\$$ Mycelium contained $2.60 \mathrm{mg}$ protein.

Table 5. Cysteinylglycine/glutathione ratio in culture filtrates after feeding $[2-14 \mathrm{C}] \mathrm{glycine}$ to Puccinia graminis tritici*

$\begin{array}{cccc}\begin{array}{c}\text { Incubation } \\ \text { time (days) }\end{array} & \begin{array}{c}\text { Cysteinylglycine } \dagger \\ \text { (d.p.m./mg protein) }\end{array} & \begin{array}{c}\text { Glutathione } \\ \text { (d.p.m./mg protein) }\end{array} & \begin{array}{c}\text { Ratio } \\ (\mathrm{C} / \mathrm{G})\end{array} \\ \text { I } & 28400 & 8950 & 3.16 \\ 5 & 56450 & 19000 & 2 \cdot 95\end{array}$

* Medium contained: $4 \%$ glucose, $0.3 \%$ citrate, Czapek's minerals, 6 mM-glutamine, 0.1 mM-methionine and $0.1 \mathrm{~mm}$-glycine at $\mathrm{pH} 6 \cdot 0$.

$\dagger$ Cysteinylglycine separated by electrophoresis at $\mathrm{pH} 3 \cdot 2$.

$\$$ Glutathione separated by electrophoresis at $\mathrm{pH} \mathbf{i} \cdot 9$.

as glycine. The S-methylcysteine sulphone and serine regions were stable to acid hydrolysis under these conditions. The suspected presence of S-methylcysteine sulphone was confirmed by co-crystallization of a sample of the culture filtrate with authentic S-methylcysteine sulphone to constant specific activity. This gave a calculated activity of 60000 d.p.m./mg protein, which agreed well with the activity of the S-methylcysteine sulphone region located on thin-layer plates (Table 4 ).

If cysteinylglycine was derived from glutathione breakdown after its release into the culture filtrate, then the cysteinylglycine/glutathione ratio would be expected to increase with prolonged incubation. This was tested by incubating the mycelium with $\left[2-{ }^{14} \mathrm{C}\right]$ glycine for one day as well as 5 days. Since a similar cysteinylglycine/glutathione ratio was obtained after both periods of exposure (Table 5), it appears that very little glutathione was breaking down to cysteinylglycine after its excretion.

\section{DISCUSSION}

Puccinia graminis tritici can synthesize substantial amounts of sulphur amino acids from $\left[{ }^{35} \mathrm{~S}\right]$ sulphide when growing in axenic culture. $\left[{ }^{35} \mathrm{~S}\right]$ Sulphate was not incorporated into any of these sulphur compounds under similar conditions which suggested that a metabolic block existed in the pathway of inorganic sulphur metabolism. Possible locations of such a metabolic block are sulphate uptake, sulphate activation or sulphate reduction. Sulphate uptake was shown to occur at a rate comparable with other fungi, thus eliminating this 
possibility. A block at sulphate activation also appears unlikely, since the end product of these reactions, adenosine $3^{\prime}$-phosphate $5^{\prime}$-phosphosulphate (PAPS), is required by the fungus for the synthesis of sulphate esters as well as sulphur amino acids. It appears more likely therefore that this fungus is unable to reduce PAPS to thiosulphate or sulphide.

More than $70 \%$ of the $\left[{ }^{35} \mathrm{~S}\right]$ sulphide incorporated into sulphur amino acids was released into the culture filtrate rather than incorporated into mycelial protein (Table 2). In this respect the wheat stem rust mycelium appears to be similar to germinating uredospores which are known to leak many metabolites (Day, Knoche \& Wiese, 1967) including sulphur amino acids (Jones \& Snow, I965). Since neither sulphide nor thiosulphate was an adequate nutritional source of sulphur (Howes \& Scott, 1972), the rate of synthesis of cysteine from sulphide was apparently not sufficient to replenish the excessive leakage of sulphurcontaining compounds and also provide adequate cysteine and methionine for a net synthesis of protein. The inability of this fungus to reduce sulphate to sulphide probably aggravated the effect of this leakage.

The loss of S-methylcysteine from the mycelium was unexpected because this fungus is unable to utilize S-methylcysteine as a nutritional source of sulphur (Howes \& Scott, 1972). It has been reported that S-methylcysteine and its sulphoxide are present in plants (Morris \& Thompson, I956), bacteria (Grabow \& Smit, I967) and other fungi (Ragland \& Liverman, 1956) although the role of these compounds in metabolism is not understood. The synthesis of S-methylcysteine from cysteine and methyltetrahydrofolate (methyl-THF) would result in the regeneration of tetrahydrofolate (THF). Jackson, Samborski, Rohringer \& Kim (I970) noted the accumulation of methyl-THF at the expense of THF during the germination of wheat stem rust uredospores upon distilled water. Perhaps the synthesis and excretion of S-methylcysteine plays an important role in the regeneration of THF in this fungus. Thus the inhibition of growth in rusts and mildews by high concentrations of methionine (Samborski \& Forsyth, I960; Dekker, I969; Howes \& Scott, I972) may be explained by the conversion of fungal reserves of THF to methyl-THF, resulting in the depletion of THF.

The accumulation of sulphur amino acids in the culture filtrate was selective; considerable amounts of cysteine and cysteine-containing peptides, but very little methionine or homocysteine appeared in the culture filtrate. This may explain why the rust fungus requires higher concentrations of cysteine than methionine for optimal growth (Howes \& Scott, 1972).

Cysteinylglycine was the major sulphur-containing compound released into the culture filtrate. This compound was first isolated from wheat germ and shown to be present in a number of different organisms (Tkachuk, 1970). A possible origin of cysteinylglycine in these organisms is from the breakdown of glutathione, catalysed by $\gamma$-glutamyltranspeptidase (reaction I),

$$
\text { glutathione }+ \text { amino acid } \rightarrow \gamma \text {-glutamylamino acid }+ \text { cysteinylglycine. }
$$

Many $\gamma$-glutamyl peptides have been isolated from plant (Morris \& Thompson, 1956), animal (Kanazawa, Katimoto, Nakajima \& Sano, 1965) and fungal (Morton \& Broadbent, I955) sources. $\gamma$-Glutamyltranspeptidase activity has been demonstrated in animal tissues (Hanes, Hird \& Isherwood, 1950) and in fungi (Waelisch, 1952).

Orlowski \& Meister (1970) have suggested that rat-kidney $\gamma$-glutamyltranspeptidase is involved in a cyclic set of reactions which they called the $\gamma$-glutamyl cycle. They proposed that the function of this cycle is the active transport of amino acids, utilizing the energy of the $\gamma$-glutamyl bond. In this scheme cysteinylglycine is broken down by a peptidase to its 
component amino acids, cysteine and glycine. These amino acids are then re-incorporated into glutathione by the ATP-requiring steps catalysed by $\gamma$-glutamylcysteine synthetase and glutathione synthetase.

The accumulation of cysteinylglycine in the culture filtrate of the rust fungus suggests that this organism does not produce peptidases capable of attacking cysteinylglycine.

A metabolic block at cysteinylglycine breakdown could prevent the completion of the $\gamma$-glutamyl cycle and cause intermediates of this cycle to accumulate. This would explain the predominance of sulphur- 35 in cysteine, glutathione and cysteinylglycine. Cysteinylglycine does not accumulate in rust-infected wheat leaves (Howes \& Scott, unpublished results), which suggests either that it is not excreted by parasitic states of the fungus or that the host contains enzymes necessary for its metabolism. If the latter is the case, this would ensure completion of the cycle.

The authors thank Dr P. R. Day and Dr T. A. Dyer for criticisms of the manuscript. Financial assistance from the Australian Research Grants Committee and the Wheat Industry Research Council of Australia is gratefully acknowledged.

\section{REFERENCES}

Barner, H. D. \& CANTINo, E. C. (1952). Nutritional relationships in a new species of Blastocladiella. American Journal of Botany 39, 746-75I.

Benko, P. V., Wood, T. C. \& Segel, I. H. (1967). Specificity and regulation of methionine transport in the filamentous fungi. Archives of Biochemistry and Biophysics 122, 738-804.

BraY, G. A. (1960). A simple efficient liquid scintillator for counting aqueous solutions in a liquid scintillation counter. Analytical Biochemistry r, 279-285.

Cantino, E. C. (1950). Nutrition and Phylogeny in the water molds. Quarterly Review of Biology 25 , $269-277$.

Cantino, E. C. (1955). Physiology and Phylogeny in the water molds-a re-evaluation. Quarterly Review of Biology 30, I $38-149$.

Daly, J. M., KNoche, H. W. \& Wiese, M. V. (1967). Carbohydrate and lipid metabolism during germination of uredospores of Puccinia graminis tritici. Plant Physiology 42, 1633-1641.

DekKer, J. (1969). L-Methionine induced inhibition of powdery mildew and its reversal by folic acid. Netherlands Journal of Plant Pathology 75, 182-185.

Delavier-Klutchko, C. \& Flavin, M. (1965). Enzymic synthesis and cleavage of cystathionine in fungi and bacteria. Journal of Biological Chemistry 240, 2537-2549.

Grabow, W. O. K. \& SMIT, J. A. (1967). Methionine synthesis in Proteus mirabilis. Journal of General Microbiology 46, 47-57.

Hanes, C. S., Hird, F. J. R. \& Isherwood, F. A. (I950). Synthesis of peptides in enzymic reactions involving glutathione. Nature, London $166,288-292$.

Heilmann, J., Barrollier, J. \& Watzke, E. (1957). Beitrag zur Aminosäurebestimmung auf Papierchromatogrammen. Zeitschrift fur physiologische Chemie 309, 219-220.

Howes, N. K. \& SCOTT, K. J. (1972). Sulphur nutrition of Puccinia graminis f. sp. tritici in axenic culture. Canadian Journal of Botany 50, I $165-1170$.

INGRAHAM, J. L. \& EMERSON, R. (I954). Studies of the nutrition and metabolism of the aquatic phycomycete, Allomyces. American Journal of Botany 4I, I46-I 52.

Jackson, A. O., SAmborski, D. J., Rohringer, R. \& KIM, W. K. (I970). Folate derivatives in ungerminated and germinated uredospores of wheat stem rust. Canadian Journal of Botany 48, I617-1623.

JONES, J. P. \& SNOW, J. P. (1965). Amino acids released during germination of $\mathrm{S}^{35}$ labelled crown rust spores. Phytopathology (Abstr.) 55, 499.

Kanazawa, A., Katimoto, Y., Nakajima, T. \& Sano, I. (1965). Identification of $\gamma$-glutamylserine, $\gamma$-glutamylalanine, $\gamma$-glutamylvaline and S-methylglutathione of bovine brain. Biochimica et biophysica acta III, 90-95.

Katz, S. \& Lewis, A. (1966). Apparatus for high-voltage thin layer electrophoresis. Application to amino acid analysis. Analytical Biochemistry 17, 300-309. 
Lowry, O. H., Rosebrough, N. J., FARr, A. L. \& Randall, R. J. (195I). Protein measurement with the Folin phenol reagent. Journal of Biological Chemistry I93, 265-275.

MAClean, D. J. \& SCOTT, K. J. (I970). Variant forms of saprophytic mycelium grown from uredospores of Puccinia graminis f. sp. tritici. Journal of General Microbiology 64, 19-27.

Maclean, D. J., ScotT, K. J. \& Tommerup, I. C. (I97I). A uninucleate wheat-infecting strain of the stem rust fungus isolated from axenic cultures. Journal of General Microbiology 65, 339-342.

Morris, C. J. \& Thompson, J. F. (I956). The identification of (+) S-methyl-L-cysteine sulfoxide in plants. Journal of the American Chemical Society 78, I605-I608.

Morton, A. G. \& Broadbent, D. (1955). The formation of extra-cellular nitrogen compounds by fungi. Journal of General Microbiology 12, 248-258.

Orlowski, M. \& MeISTER, A. (I970). The $\gamma$-glutamyl cycle: A possible transport system for amino acids. Proceedings of the National Academy of Science of the United States of America 67, 1248-1255.

RAgland, J. B. \& Liverman, J. L. (1956). S-Methyl-L-cysteine as a naturally occurring metabolite in Neurospora crassa. Archives of Biochemistry and Biophysics 65, 574-576.

Ryan, F. J., Beadle, G. W. \& TATUM, E. L. (I943). The tube method of measuring the growth rate of Neurospora. American Journal of Botany 30, 784-799.

Samborski, D. J. \& Forsyth, F. R. (1960). Inhibition of rust development of detached wheat leaves by metabolites, antimetabolites, and enzyme poisons. Canadian Journal of Botany 38, 467-476.

SchmidT, G. \& ThanNhauser, S. L. (1945). A method for the determination of deoxyribonucleic acid, ribonucleic acid and phosphoproteins in animal tissue. Journal of Biological Chemistry, 16r, 83-89.

Thompson, J. F. (1967). Sulphur metabolism in plants. Annual Review of Plant Physiology 18, 59-84.

TKACHUK, R. (1970). L-Cysteinylglycine: its occurrence and identification. Canadian Journal of Biochemistry 48, $1029-1036$.

WAELISCH, H. (1952). Certain aspects of intermediary metabolism of glutamine, asparagine and glutathione. Advances in Enzymology 13, 237-319. 